\title{
夏季成層期の有明海における乱流エネルギー散逸率の時空間変動

\author{
Spatio-Temporal Variations of Turbulent Energy Dissipation Rate during Stratification \\ Period in Ariake Bay
}

\author{
田井 明 $^{1} \cdot$ 志岐慎介 $^{2} \cdot$ 齋田倫範 $^{3} \cdot$ 矢野真一郎 $^{4} \cdot$ 小松利光 $^{5}$
}

\begin{abstract}
Akira TAI, Shinsuke SHIKI, Tomonori SAITA, Shinichiro YANO and Toshimitsu KOMATSU
In recent years in-situ measurements on microstructures are carried out to investigate turbulence structures in shallow sea areas. However it is difficult to figure out turbulent structures near interfaces, such as sea beds, sea surfaces and pycnocline, because of the measuring principle of a commonly-used shear sensor. In this study, field observations on microstructures were carried out in Ariake Bay by using the microstructure profiler which acquires fine-scale temperature gradients. As a result of these observations, spatio-temporal variations of turbulent energy dissipation rate in the northern area of Ariake Bay were observed and it is clarified that the way to estimate turbulent energy dissipation rate from temperature gradients in shallow sea areas is valid especially under strongly stratified condition.
\end{abstract}

\section{1.はじめに}

有明海では貧酸素水塊の大規模化・長期化が問題とな っている.この筫酸素水塊の消長を再現・予測可能な数 值モデルを開発することは有明海異変の原因や対策を検 討するために有用である，貧酸素化には密度成層の形成 による酸素供給の減少, ならびに密度効果によって駆動 されたエスチャリー循環による有機物の輸送が大きく影 響するため（徳永ら，2009; 速水ら，2006）, 密度成層 の形成・崩壊過程を高精度に再現可能な乱流モデルが必 要になる。 そのためには実海域における乱流構造の定量 的な把握が重要であることから, 微細構造プロファイラ を用いた沿岸域での現地観測が実施されている（長尾ら， 2004). 有明海では齋田ら（2009）などによって現地観 測が行われており, 乱流エネルギー散逸率 $\varepsilon$ や鉛直渦動 粘性係数 $K z$ の時間変動が示されている.また, 齋田ら （2008）は同様の観測によって大浦沖は島原半島沖に比

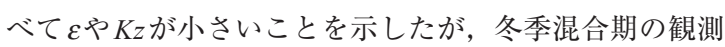
結果であるため, 夏季成層期に関する再検証が必要であ る.さらに, 従来の乱流シア測定ではシアセンサーが等 速運動を行っていなければならないという測定上の制約 から, 測定開始直後や密度躍層通過時といった測定機器 が加減速を生じる領域のデー夕は利用できない. 特に, 水深 $20 \mathrm{~m}$ 以下程度の浅海域では取得したデー夕の大部分 が利用できなくなるため，有明海北部海域のように密度 躍層が存在する浅海域への微細構造プロファイラの適用

$\begin{array}{llll}1 & \text { 正会員 } & \text { 博 (工) } & \text { 九州大学大学院特任助教 } \\ 2 & & \text { 修 (工) } & \text { 三菱重工業株式会社 } \\ 3 & \text { 正会員 } & \text { 博 (工) } & \text { 鹿児島大学大学院助教 } \\ 4 & \text { 正会員 } & \text { 博(工) } & \text { 九州大学大学院准教授 } \\ 5 & \text { フエロー } & \text { 工博 } & \text { 九州大学大学院教授 }\end{array}$

に際しては改善すべき点が多く残されている。このよう な背景から，同海域における夏季の乱流構造に関しては 十分な知見が得られていないのが実状である.

そこで, 本研究では前述のような測定上の制約を受け ない温度シアによる った.さらに, 混合海域とされる有明海島原半島沖から 成層海域とされる大浦沖にかけての海域の乱流構造の時 空間変動特性について評価を行った.

\section{2. 観測概要}

\section{（1）島原半島沖での定点観測（観測 I）}

本研究では, 有明海における 2 回の観測で得られたデ ー夕を用いて解析を行った。一つは，2007年 8 月 24 日 (中潮期) に一潮汐間にわたって実施された観測（観測 I) である。測点は, 図-1に示す点 $\mathrm{S}\left(32^{\circ} 51^{\prime} 56^{\prime \prime} \mathrm{N}, 130^{\circ}\right.$ $\left.21^{\prime} 27^{\prime \prime} \mathrm{E}\right)$ である. 微細構造の測定は, 錘を取り付けた 微細構造プロファイラ TurboMAP9（JFEアレック社製：

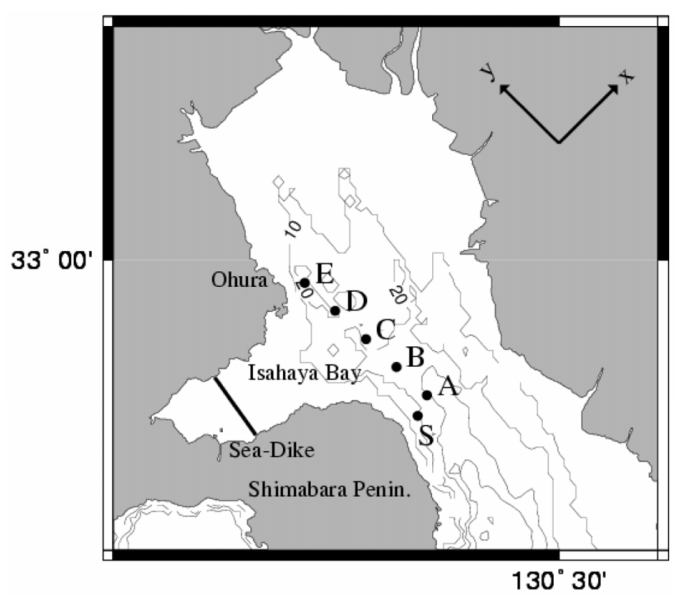

図-1 対象海域と観測地点 


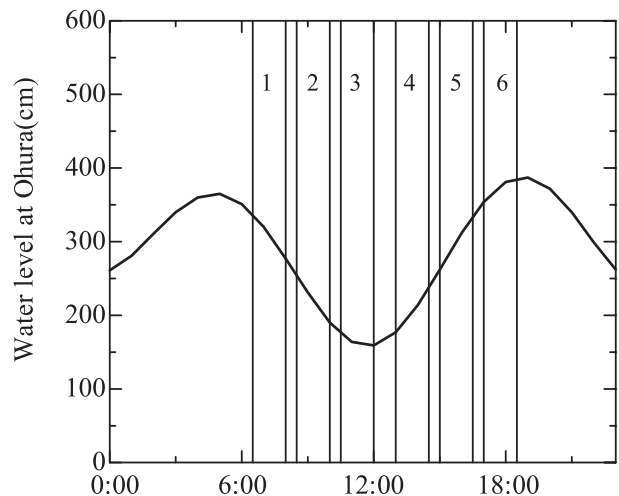

図-2 観測実施時の潮汐と観測時間帯（観測 II）

以下TurboMAP）を海底まで沈めた後に錘を切り離して 海面に向かって $0.5 \mathrm{~m} / \mathrm{s}$ で自由浮上させる方法（上昇式） で実施した。この観測の詳細ならびに乱流シアを用いた 解析結果は既に齋田ら（2009）によって報告されている。

\section{（2）島原半島沖での定点観測（観測 II）}

観測 II は，諫早湾湾口に沿った時空間分布を把握する ことを目的として，2009年8月1日（小潮期）に図-1に 示す $A \sim E$ の 5 測点における測定を 1 セットとし，一潮汐 間に6セット実施したものである（図-2）．鉛直微細構造 の測定にはTurboMAPを使用し, 約 $0.5 \mathrm{~m} / \mathrm{s}$ で自由落下さ せる方法（下降式）で測定した.なお， 1 測点につき 3 回 のデー夕取得を行った。 また, 平均流の測定には超音波 ドップラー流速計W orkhorseADCP600kHz（RDInstruments社製）を用いた。

\section{3. データ解析}

\section{（1）TurboMAPの上昇および下降速度について}

シアセンサーによる乱流シア測定の主な制約条件とな る TurboMAPの上昇および下降速度について検討を行っ た. TurboMAPは上昇式の場合には海底から上昇を開始 した直後から加速して一定の速度になる．同様に下降式 の場合にも海面から投入した直後から加速して一定の速 度になる。シアセンサーによる測定では, これらの著し く加速度が大きい区間は欠測として扱われる。また，強 く密度成層している海域では, 密度躍層での TurboMAP に作用する浮力の急激な変化に伴って上昇および下降速 度が変化する。ここでは, 簡単な計算により, 海水密度 の変化によって生じるTurboMAP上昇時の速度変動につ いて議論する. TurboMAPの体積, 投影面積, 密度, 抵 抗係数をそれぞれ $V, S, \rho_{T}, C_{D}$, 海水密度を $\rho_{f}$, 重力加 速度を $g$ とすると TurboMAPに作用する力のつりあいと それから求められる終端速度は,

$$
V \rho_{f} g-V \rho_{T} g-\frac{1}{2} \rho_{f} v^{2} S C_{D}=0
$$

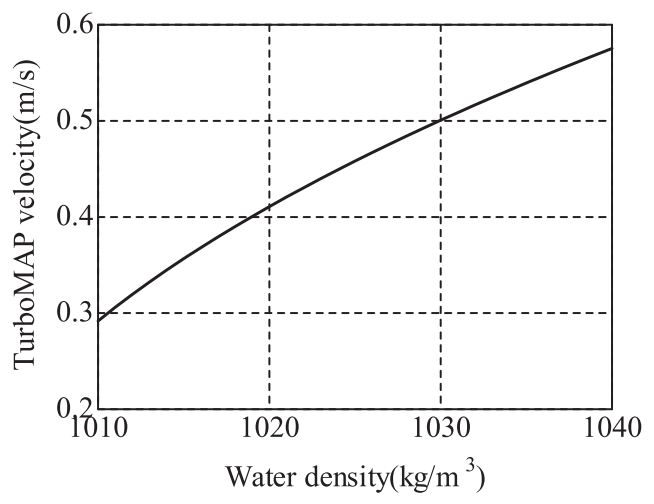

図-3 海水密度とTurboMAPの終端速度の関係

$$
v^{2}=\frac{2 V g\left(\rho_{f}-\rho_{T}\right)}{\rho_{f} S C_{D}}
$$

となる. 式 (1) 右辺第一項は浮力項, 第二項は重力項, 第三項は流体中を進む際に生じる抗力である.この式か ら上昇速度を求めるために, TurboMAP本体の抵抗係数 $C_{D}$ を求める. 通常 TurboMAPの上昇速度を $0.5 \mathrm{~m} / \mathrm{s}$ 前後に 調整することから $v=0.5 \mathrm{~m} / \mathrm{s}$ とし, TurboMAPを長さ $l=1.8 \mathrm{~m}$, 底面は半径 $r=0.06 \mathrm{~m}$ の円柱形, $\rho_{T}=1000 \mathrm{~kg} / \mathrm{m}^{3}$, $\rho_{f}=1030 \mathrm{~kg} / \mathrm{m}^{3}$ として（1）から算出すると,

$$
C_{D}=\frac{2\left(\pi r^{2} l\right) g\left(\rho_{f}-\rho_{T}\right)}{\rho_{f} \pi r^{2} v^{2}}=4.1
$$

となる。この值を用いて式（2）より求めた海水密度と TurboMAPの終端速度との関係を図-3に示す。これは後 述する実測值ともよく一致しており, 密度成層が発達し た状況下で乱流シアデータを用いる際には注意を要する ことを示している.

\section{（2）乱流シアによる乱流エネルギー散逸率 $\varepsilon_{S}$ の算出}

齋田ら（2009）と同様の方法を用いて乱流シアデータ から乱流エネルギー散逸率 $\varepsilon_{S}$ の算出を行った. TurboMAP によってサンプリング周波数 $512 \mathrm{~Hz}$ で測定された乱れ速 度 $u^{\prime}$ の鉛直シアから得られたパワースペクトル $\phi(\mathrm{k}) よ$ り, 等方性を仮定して導かれる以下の式（4）を用いて層 厚 $1 \mathrm{~m}$ 毎に乱流エネルギー散逸率 $\varepsilon_{S}$ を算出した.

$$
\varepsilon_{S}=\frac{15}{2} v \overline{\left(\frac{d u^{\prime}}{d z}\right)^{2}}=\frac{15}{2} v \int_{k_{1}}^{k_{2}} \phi(k) d k
$$

ここで， $v$ は動粘性係数であり，TurboMAPによって測定 された塩分, 水温の值を用いて層毎に算定した， $k_{1}$ は乱 流シアのスペクトルを算出する際の層厚を $1 \mathrm{~m}$ に設定し たため $1 \mathrm{cpm}$ とした。さらに, 式（5）から求まる Kolmogorovスケールの波数 $k_{s}$ と $k_{2}$ との比較を行いながら $k_{2}$ を変化させて計算を繰り返し， $k_{2}$ と $k_{s}$ とが等しくなっ た時点での $\varepsilon_{S}$ を結果として用いた. 


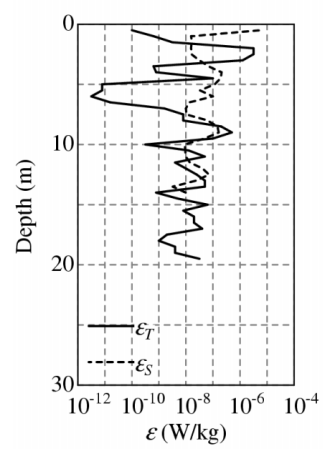

(a) 6:47 の結果

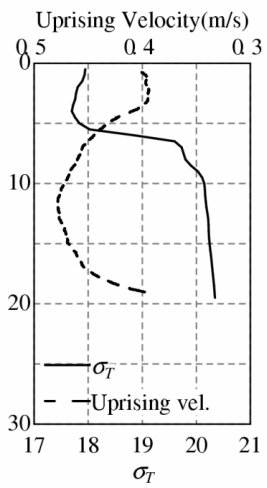

図-4 $\varepsilon_{T}, \varepsilon_{S}, \sigma_{T}$, 浮上速度の関係（観測 $\mathrm{I}$
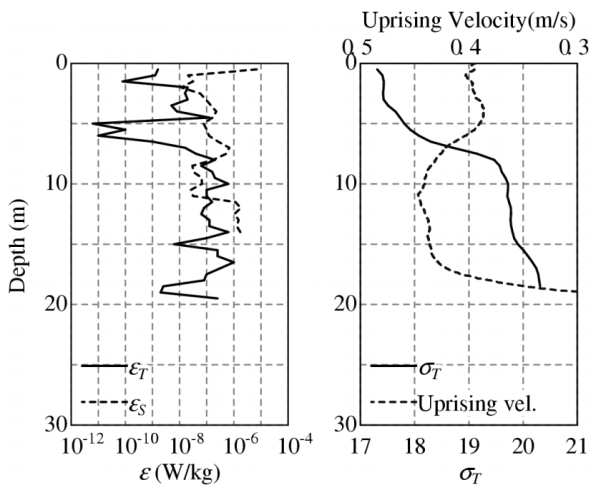

(b) 9:39 の結果

$$
k_{s}=\left(\frac{\varepsilon_{S}}{v^{3}}\right)^{1 / 4}
$$

機器の振動によって生じるノイズの波数（波数 $300 \mathrm{cpm}$ 付近）よりも $k_{2}$ が高波数側にある場合には，Nasmyth ス ペクトル（Nasmyth,1970）を積分した.

（3）温度シアによる乱流エネルギー散逸率 $\varepsilon_{T}$ の算出

TurboMAPに搭載された温度シアセンサーFPO7により サンプリング周波数 $512 \mathrm{~Hz}$ で測定された温度シアデータ $d T^{\prime} / d z$ から温度シアの理論スペクトルである Batchelor ス ペクトル（Batchelor, 1959）を用いて乱流エネルギー散逸 率 $\varepsilon_{T}$ を算出した。式（6）～（9）にRoget（2006）による Batchelorスペクトルの関数を示す.

$$
\begin{aligned}
& E_{\frac{d T T^{\prime}}{d z}}(k)=\frac{\chi_{0} q^{1 / 2}}{D \kappa_{B}} y^{2}\left\{\frac{\exp \left(-y^{2}\right)}{y}-\sqrt{\pi}(1-\operatorname{erf}(y))\right\} \\
& \operatorname{erf}(y)=\frac{2}{\sqrt{\pi}} \int_{0}^{y} \exp \left(-x^{2}\right) d x \\
& y=2 \pi k \kappa_{T}^{1 / 2} v^{1 / 4} q^{1 / 2} \varepsilon^{1 / 4} \\
& \kappa_{B}=\left(\varepsilon_{T} / v D^{2}\right)^{1 / 4}
\end{aligned}
$$

$y$ は無次元化された波数, $\kappa_{B}$ は Batchelor スケールに対応 する波数， $\kappa_{T}$ は熱伝導率である. $\chi_{0}$ は温度シアのパワー スペクトル $\phi_{T}$ を積分して以下の式（10）から得られる.

$$
\begin{aligned}
& \chi_{0}=6 D \overline{\left(\frac{\partial T^{\prime}}{\partial z}\right)^{2}}=6 D \int_{k_{1}}^{k_{3}} \phi_{T}(k) d k \\
& D=\kappa_{T} / \rho c_{p}
\end{aligned}
$$

$D$ は熱拡散率であり, 各層の海水密度 $\rho$, 比熱容量 $c_{p}$ お よび熱伝導率 $\kappa_{T}$ から求められる。 $k_{3}$ は測定回によって異 なるが，スペクトルが十分減衰していると思われる $3000 \mathrm{cpm}$ 程度とした。

算出は，測定された温度シアから層厚 $1 \mathrm{~m}$ ごとにパワ

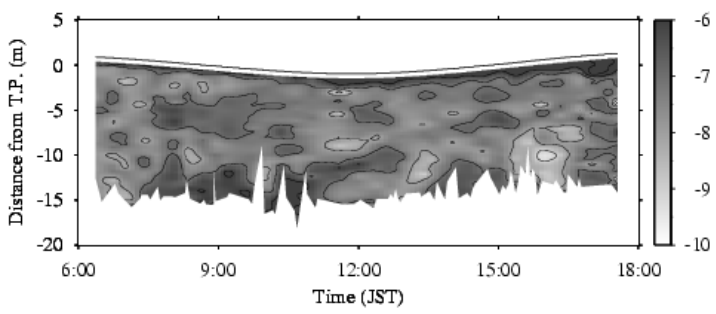

(a) 乱流シアより算出した $E S$

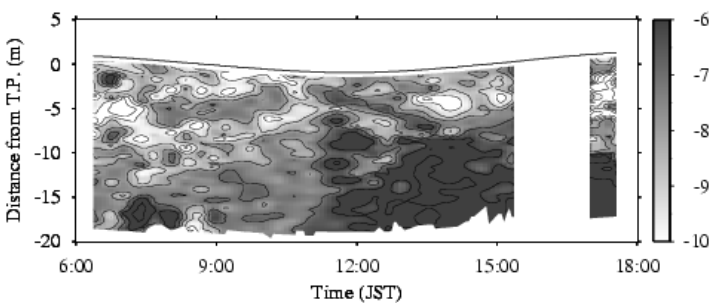

(b) 温度シアより算出した $\varepsilon T$

図-5＼cjkstart観測Iにおける $\log \varepsilon$ のイソプレット（W/kg）

ースペクトルを求め，そのスペクトルに式（6）に示し た Batchelorスペクトルを最小二乗法によりフィッティン グさせて最適な $\varepsilon_{T}$ を求めた（Ruddickら，2000）。 その際， $\chi_{0}$ の值は $\phi_{T}(k)$ を積分して得られる值を用いた。なお， 式（6）（8）中の $q$ にいては，2.2～5.2 程度であるこ とがOakey（1982）によって示されている. 本研究では, $q$ の值を 2.0 〜 5.0 として各層ごとに最小二乗法を用いて 最適な值を用いた。

\section{4. 結果と考察}

\section{（1）密度躍層における $\varepsilon_{S}$ と $\varepsilon_{T}$ の比較}

図-4に観測Iにおける $\varepsilon_{S}, \varepsilon_{T}, \sigma_{T}$ およびTurboMAPの浮上 速度の代表的な鉛直分布を示す。なお， $\varepsilon_{S}, \varepsilon_{T}$ は $\log$ スケ ールで表示してある， $\sigma_{T}$ と浮上速度の鉛直分布から，水 深 5〜 10mに発達した密度躍層付近でTurboMAPが減速 していることが分かる。ここで， $\varepsilon_{S} に$ 関しては 


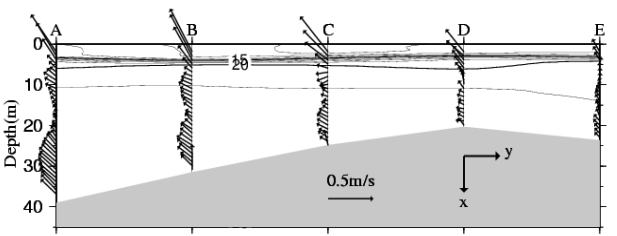

(a) 1 回目

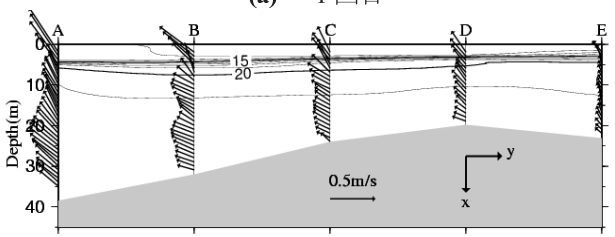

(b) 2 回目

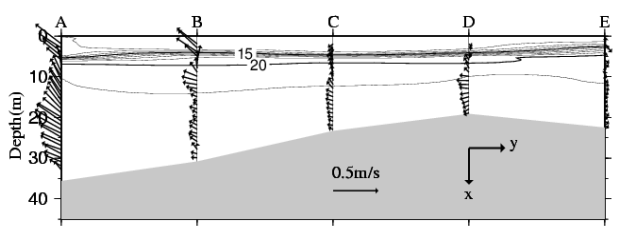

(c) 3 回目

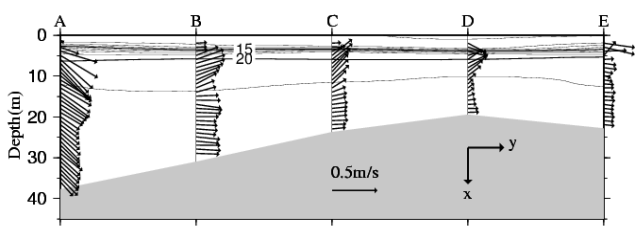

(d) 4 回目

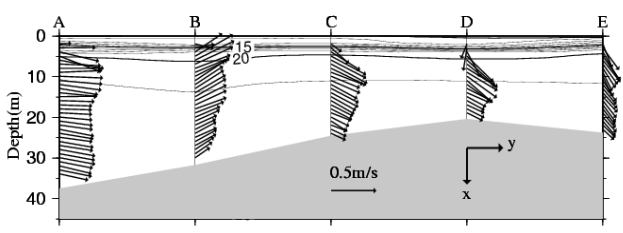

(e) 5 回目

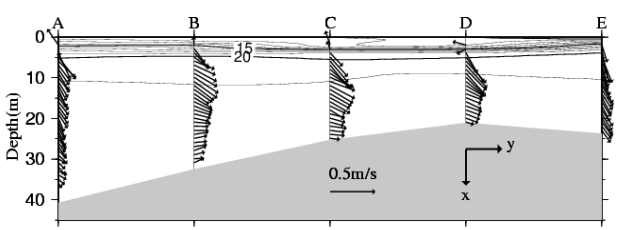

(f) 6 回目

図-6 $\sigma_{T}$ (コンター線) と水平平均流速の分布

TurboMAPが減速している区間についても比較のために 值を表示している.

密度躍層付近に抒ける $\varepsilon_{T}$ の值は，他の層と比べて小さ くなっており，密度躍層による乱れの抑制がとらえられ ていると考えられる，一方， $\varepsilon_{S}$ の值には密度躍層付近で

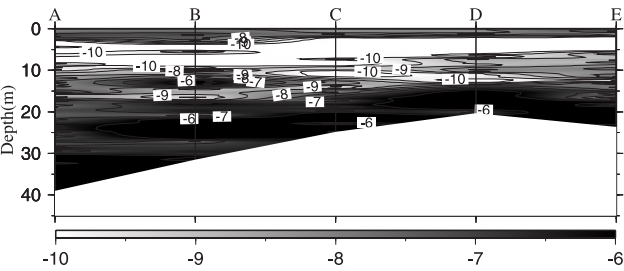

(a) 1 回目

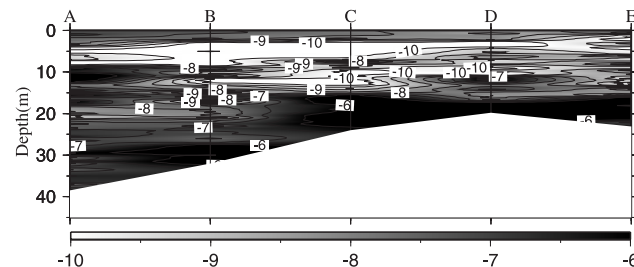

(b) 2 回目

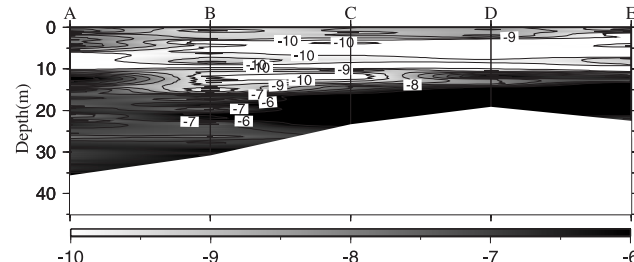

(c) 3 回目

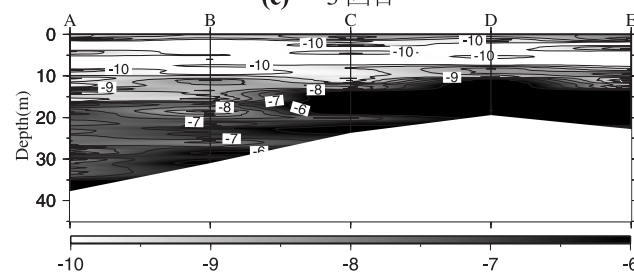

(d) 4 回目

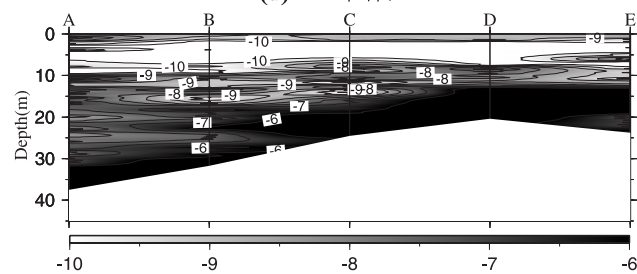

(e) 5 回目

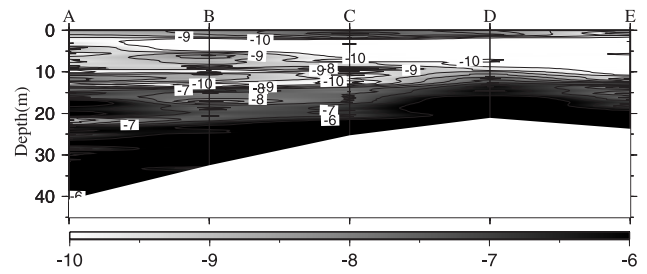

(f) 6 回目

図-7 $\log \varepsilon_{T}$ の分布 $(\mathrm{W} / \mathrm{kg})$

の変化がほとんど現れなかった，次に，齋田ら（2009） により示された $\varepsilon_{S}\left(\right.$ 図-5 (a)) と本研究で算出した $\varepsilon_{T}$ (図-5 (b)）のイソプレットの比較を行う， $\varepsilon_{S}$ では鉛直方 向にほとんど変化がなく一様なのに対し， $\varepsilon_{T}$ では，密度 躍層の生じていた $5 \mathrm{~m}$ 付近で底層に比べて值が低くなっ 
ていることが分かる.これらは, TurboMAPの加減速の 影響により，乱流シアデータから算出した $\varepsilon_{S}$ では密度躍 層における乱れの抑制を正確に評価できていないことを 示している．また，温度シアは上昇開始直後の加速区間 のデータや密度躍層付近のデー夕を用いることができな い乱流シアに比べ, 乱流エネルギー散逸率を算出可能な 区間が多いことが分かる。これらより, 密度躍層が発達 している海域においては温度シアを用いた乱流エネルギ 一散逸率の測定が有用であることが示された.

\section{（2）時空間分布特性について}

次に，観測IIによって得られた結果より，有明海中央 部の乱流エネルギー散逸率の時空間分布特性についての 検討を行う。図-6に $\sigma_{T}$ ならびに超音波ドップラー流速計 によって得られた水平平均流速，図-7に温度シアより算 出された $\varepsilon_{T}$ の空間分布を測定回毎に示す. 全測定回で $\varepsilon_{T}$ が表層と底層付近で大きくなっていることが分かる．水 深 $5 \mathrm{~m}$ から $20 \mathrm{~m} て ゙ は ，$ 地点間で流速の大きさが大きく異 なるものの, $\varepsilon_{T}$ は全地点で同程度の值となっている。ま た，A点では底層付近と中層付近で流速の大きさが同程 度であっても $\varepsilon_{T}$ が大きく異なる観測回が多い。これは, $\varepsilon_{T}$ が流速の大きさのみからは推定できないことを示して いる.さらに，下げ潮時（1回目 $\rightarrow 2$ 回目）ならびに上げ 潮時（4回目 $\rightarrow 5$ 回目）には底層から乱れが発達し，満潮 時 (5 回目 $\rightarrow 6$ 回目) と干潮時（2回目 $\rightarrow 3$ 回目）には乱 れが減衰していることが分かる，以上のように時間的・ 空間的な $\varepsilon_{T}$ の変動は見られるものの, 表層から密度躍層 の生じる中層に着目すると, 夏季成層期には流速が大き い島原半島沿岸（測点 $\mathrm{A}$ 付近）と流速の小さい大浦沖 (測点 $\mathrm{E}$ 付近) とで, 鉛直混合力の指標となる乱流エネル ギー散逸率に大きな違いはないことが明らかとなった。

\section{5. まとめ}

本研究では，夏季成層期の有明海において温度シアデ ー夕を用いて乱流エネルギー散逸率を算出し, その有用 性を示した。今後, 乱流シアによる乱流エネルギー散逸 率の推定が困難な領域を温度シアによる推定值で補完す ることで，浅い沿岸域における乱流構造の観測が可能に
なると考えられる．さらに，その手法を用いて夏季成層 期の有明海の乱流エネルギー散逸率の時空間分布が定量 的に示されたことから，今後この結果を利用することで 乱流モデルならびに数值モデルの精度向上が期待される.

謝辞：本研究を実施するにあたり，有明町漁業協同組合 の松本正明氏，宮本雄二氏ならびに篠塚光信氏には現地 観測の際に多大なる御協力を頂きました。ここに記して 深甚なる謝意を表します。最後に，本研究は科学研究費 補助金若手研究（B）（課題番号：20760333，研究代表 者：齋田倫範）の補助を受けて実施したことを付記する.

\section{参 考 文 献}

齋田倫範 · 志岐慎介 ・ 田井 明 - 重田真一 ·矢野真一郎 - 小 松利光 (2009)：現地観測による島原半島沿岸の鉛直混合 強度の評価, 水工学論文集, 第53巻, pp.1471-1476.

齋田倫範 · 矢野真一郎 - 田井 明 - 志岐慎介 - 重田真一 - 小 松利光 (2008) : 冬期有明海における鉛直混合強度の現地 観測，海岸工学論文集，第 55巻，pp421-424.

速水祐一 - 山本浩一 - 大串浩一郎 - 濱田孝治 - 平川隆一 - 宮 坂仁・大森浩二 (2006) : 夏季の有明海奥部における懸濁 物質輸送とその水質への影響，海岸工学論文集，第 53 巻, pp.956-960.

徳永貴久·児玉真史・木元克則・柴原芳一（2009）：有明海湾 奥西部海域における貧酸素水塊の形成特性，土木学会論 文集 B2 (海岸工学), Vol. B2-65, pp.1011-1015.

長尾正之・橋本英資・高杉由夫（2004）：瀬戸内海における鉛 直混合強度の測定，海岸工学論文集，第 51 巻，pp.946950.

Batchelor G. K. (1959) : Small-scale variation of convected quantities like temperature in turbulent fluid : Part 1. General discussion and the case of small conductivity, Journal of Fluid Mechanics, Vol.5, pp.113-133.

Nasmyth, P.W. (1970) : Oceanic Turbulence, Ph.D thesis (The University of British Columbia), p.69.

Oakey N. S. (1982) : Determination of the rate of dissipation of turbulent energy from simultaneous temparature and velocity shear microstructure measurements, Journal of Physical Oceanography, Vol.12, pp.256-271.

Roget, E., I. Lozovatsky, X. Sanchez, M. Figueroa (2006) : Microstructure measurements in natural waters: Methodology and applications, Progress in Oceanography, Vol.70, pp.126148.

Ruddick B., A. Ayal, K. Thompson (2000) : Maximum Likelihood Spectral Fitting: The Batchelor Spectrum., Journal of Atmospheric and Oceanic Technology, Vol.17, pp.1541-1552. 